\title{
Sociology Review of Social Phenomenon, Social Rules and Social Technology
}

\author{
Dadang Hartanto \\ Lecturer at Muhammadiyah University, North Sumatera, Indonesia \\ dadanghartanto@umsu.ac.id
}

\begin{abstract}
Law is a rule that was born, lived and developed in the midst of society. There are laws that come from religious norms or norms that originate from God; norms or rules of decency originating from the hearts of human beings; norms or rules of politeness, that is the rules of life arising from association, the interaction of human groups in society and regulating human behavior towards other humans; as well as legal norms or rules that are rules made by the authorities whose contents are binding on everyone and their implementation can be defended by force by state instruments. Because the law is very urgent, it must be as flexible as possible. The law must be able to adjust to the dynamics of people's lives very quickly, because of the development of science and technology. Law is very or even must be able to deal with various changes that exist. If they are unable, the people as legal subjects will lose faith in the law. This paper talks about law as a social phenomenon of social principles and social technology in the lens of legal sociology.
\end{abstract}

Keywords

social phenomena; social rules; social technology

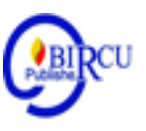

\section{Introduction}

When talking about law, it can be seen from various aspects. For example, from the aspects of economics, philosophy, history, social, health and others. Law is a social phenomenon or phenomenon that is born, grows, develops in the midst of society. The function of law in the midst of society is as a tool and social and engineering control (law as a tool of social engineering) as an extension of the authorities. ${ }^{1}$ The existence of law in the midst of society is a necessity caused by the desires to achieve peace and order in society.

Satjipto Rahardjo said that the law is an institution that aims to bring people to a just, prosperous life and make people happy. ${ }^{2}$ As an institutionalized institution in society, of course the law is vulnerable to various changes, and rightfully so. Many aspects that make the law may not be static but dynamic as the dynamic of the existing social life.

Therefore the law must not close itself to the changes that exist, in harmony and in line with the times and dynamics of community life. Ahmad Musthafa al-Maraghi argued that in fact the laws were made and promulgated for the benefit of humans, while the interests of humans were not the same, different from one another due to differences in conditions and situations, time and place. ${ }^{3}$ Therefore, if a law is made at a time when the law is felt as a

\footnotetext{
${ }^{1}$ Nur A. Fadhil Lubis, Hukum Islam Dalam Kerangka Teori Fikih dan Tata Hukum Indonesia, Widya Sarana, Medan, 1995, Cet. Ke-1, P. 97

${ }^{2}$ Satjipto Rahardjo, Hukum Progresif Sebuah Sintesa Hukum Indonesia, Genta Publishing, Yogyakarta, 2009, P. 2.

${ }^{3}$ Ahmad Musthafa al-Maraghi, Tafsir al-Maraghi, Juz. I, Bab al-Baby al-Halaby, Kairo, t.th., P. 182.
} 
need, then that need is no longer present, then a very wise matter is changed and adjusted to the conditions of the times. ${ }^{4}$

When viewed sociologically, modern and simple society always requires justice and legal certainty. Therefore, the community makes rules that are collectively recognized as guidelines and references in determining the boundaries of rights and obligations called rules. Anomalies for this rule will be rewarded or rewarded by legal sanctions in accordance with applicable regulations. All of this shows that in every society there is a means that regulates the order of life, that is the law.

Law is a social network that regulates all angles of culture with no real limits. The actual law cannot be sharply distinguished from the form of social behavior. ${ }^{5}$ law is also the work of humans in the form of norms containing behavioral guidelines which are a reflection of human will about how society should be fostered and where it should be directed. ${ }^{6}$

This paper will refer to the law as a social phenomenon, social rules and social technology in the review of legal sociology. The direction to be achieved from this paper is that legal changes can occur due to social phenomena, developing social rules and social technology.

\section{Discussion}

\subsection{Law as a Social Phenomena}

The community is always experiencing changes. The difference is only in the nature or degree of change. The change can be seen clearly or not, sooner or later, it can be related to issues that are related and are fundamental to the community concerned or only small changes. But whatever the nature and extent of the change, people always experience it. ${ }^{7}$

Society is not only a collection of a number of people, but it is also organized into groupings and institutions. The interests of community members are not always the same. However, the same interests encourage grouping among them. Besides these groupings, institutions also emerge that show that there is a joint effort to deal with a problem area in society, such as economics, politics, religion and so on. ${ }^{8}$

The more a society develops, the more groupings and institutions are formed. The formation of new groupings or the dissolution of old groupings will affect the composition of the community concerned. Likewise, the arrival of the middle class has changed the composition and balance of society which was originally determined by the nobility and religion. ${ }^{9}$

Thus the more groupings that occur in a society with a certain level of development, the areas of touch between the groups will also increase. With the emergence of groupings or classifications, society is increasingly divided or compartmentalized into separate units from the others.

For transcendental phenomenology, the existence of reality as an "object" is strictly emphasized. Active awareness in capturing and reconstructing awareness of a symptom is

\footnotetext{
${ }^{4}$ Abdul Manan, Aspek-Aspek Pengubah Hukum, Kencana, Jakarta, 2006, Cet. Ke-3, P. 4.

${ }^{5}$ Soerjono Soekanto, Antropologi Hukum, Materi Pengantar Ilmu Hukum Adat, Raja Grafindo Persada, Jakarta, 1984, P. 8.

${ }^{6}$ OK. Chairuddin, Sosiologi Hukum, Sinar Grafika, Jakarta, 1991, P. 91.

${ }^{7}$ Soerjono Soekanto, Sosiologi Suatu Pengantar, Yayasan Penerbit UI, Jakarta, 1978, P. 215.

${ }^{8}$ Satjipto Rahardjo, Hukum dan Masyarakat, Angkasa, Bandung, 1998.

${ }^{9}$ Ibid.
} 
important. For the exclusionary phenomenology, the determination of cultural phenomena depends solely on the individual. (Amal, 2018)

Every community during its lifetime must have experienced changes. There are changes that do not attract people's attention, some have broad influence, some occur slowly and some occur quickly, some are planned and so on. For someone who has conducted research on the composition and life of a community at one time and compared it another time, changes will occur in it. For example, people often say that rural life is not progressing and is not changing. Such statements are usually based on mere glance. Because there is not a single society that stops altogether in the development of his life throughout the ages. When the process changes, there is usually a force that is at the forefront of the change.

As is usual the legal experts argue that law is a social phenomenon that originates in society and is used to regulate forms of relations within the community itself. The law can affect the behavior of individuals and groups in society itself. In this regard Timashef as quoted by Adam Podgorechi and Christopher J. Whelan said: "Generally legal norms will clearly determine human behavior in society". ${ }^{10}$

The law turns out to be able to provide solutions to so many impasse problems that cling to the human mind. For example in determining the rights and obligations that should go hand in hand, but often surrounded by parties who have greedy traits, so that more demands on rights than carrying out obligations. The law has such a role that everything related to the relationship between one individual and another can take place in an orderly and orderly manner, because the law will firmly determine the rights and obligations between those who have a relationship. ${ }^{11}$

Many problems relating to legal issues can be answered positively, elegantly and with dignity by studying law as a social phenomenon. The basis of a law or rule of law is the assumption that there is a relationship between various patterns of behavior that are transformed into the form of law with the real behavior of individuals. Of course it is not strange that many people dispute that assumption. If a law is later stipulated that driving a car on the highway must be on the right, then everyone will obey the law, or at least most people will obey the law. This shows that the law has the ability to influence human behavior. ${ }^{12}$ Finally, in legal society it is no longer a necessity or obligation but has become a necessity.

The law is a measure or measure of behavior or a common attitude (standard of conduct) that must be obeyed by every community. The law also functions as an engineering to change society towards a more perfect direction (as a tool of social engineering), as a tool to check whether a behavior is true (as a tool of justification), and the law is also a means of controlling thought and steps human steps so that they are protected from violating legal norms. ${ }^{13}$

Many phenomena or events that occur in the midst of society due to various social changes that occur, have complete and complex implications to be resolved immediately by the state. It is important to find a solution so that there is no acute social conflict in the community. At a time like this the law must be able to mediate the conflict as an arbitrator for the community.

Based on these various events the law was born as a concrete manifestation of the law. Empirical facts show that the birth of many laws based on social phenomena that occur in

\footnotetext{
${ }^{10}$ Adam Podgorechi, Christopher J. Whelan, Pendekatan Sosiologi Terhadap Hukum, Penterjemah Widyaningsih, G. Karta Saputra, Bina Aksara, Jakarta, 1987, P. 253.

${ }^{11}$ Soedjono Dirdjosisworo, Pengantar Ilmu Hukum, Rajawali Pers, Jakarta, 1988, Cet. Ke-2, P. 126.

${ }^{12}$ Adam Podgorechi, Christopher J. Whelan, op.cit., P. 254.

${ }^{13}$ Baharuddin Lopa, Permasalahan Pembinaan dan Penegakan Hukum di Indonesia, Bulan Bintang, Jakarta, 1997, P. 31.
} 
society. Something that is considered taboo or not good (immoral) in society is not uncommon as an instrument for making laws.

Suparman Usman said that the law is actually moral which has been raised to the level of legality for the people, so that it becomes the law as a standard of morality. ${ }^{14}$ So it starts with habits that are considered bad by the people, then the state of bad habits is then raised to a higher level that is legalized in the form of laws plus legal sanctions.

The way this law works shows that the more complex the relationships found in society, the more laws are needed to regulate these relationships. The existence of law in the midst of society is something that arises as a result of social processes which subsequently grow into social phenomena in society. The relationship between social phenomena and social processes is very close and inseparable, where social processes are interpreted as ways of contact that can be seen when individuals and groups of people meet and determine the systems and relationships. ${ }^{15}$

The series as a social phenomenon that grows based on social processes in society is a natural fact by keeping in mind the needs of the community of the importance of order and social order. Therefore the emergence of institutions in society such as marriage, inheritance, ownership, buying and selling and so on is not caused by the existence of law, but rather it already exists as a creation and social process that runs within that society. ${ }^{16}$

To give an understanding of law as a social phenomenon that arises from social processes, the factors that must be used by the law will be stated, namely:

1. It must consist of physical and psychological facts, such as facts about sex, climate and so on. Religious traditions and folk customs and so on.

2. It must include all the facts, traditional, environmental conditions that process the facts in a certain way.

3. It consists of principles that are born from consideration based on obligations regarding human relations, such as justice, respect and others.

4. He includes the dynamic element, therefore he includes the moral aspirations of a certain period and civilization. ${ }^{17}$

Through the services of legal experts, these factors are processed through legal techniques so that the results will be in accordance with the needs of the community. For this reason marriage institutions for example would not exist if there were no men and women. The law only accepts these factors and then organizes them according to the institutions needed in connection with the reality.

\subsection{Law as a Social Rules}

The rule comes from the Arabic "qa'idah" which is the single word of the word jama "Qawa'id". Now the word rule has been absorbed into Indonesian. In the study of legal science, the rules have several definitions including the following: ${ }^{18}$

1. General law, covering subsections that are in it.

\footnotetext{
${ }^{14}$ Suparman Usman, Hukum Islam Asas-Asas dan Pengantar Studi Hukum Islam dalam Tata Hukum Indonesia, Gaya Media Pratama, Jakarta, 2001, P. 79

${ }^{15}$ OK. Chairuddin, op.cit., P. 86.

${ }^{16}$ OK. Chairuddin, op.cit., P. 86.

${ }^{17}$ W. Friedman, Legal Theory, Stevens \& Sons Limited, London, Edisi ke-4, 1960, P. 231-232.

${ }^{18}$ Ahmad Kamil, M. Fauzan, Kaidah-Kaidah Hukum Yurisprudensi, Kencana, Jakarta, 2008, Cet. Ke-3, P 1.
} 
2. Comprehensive law that is used as a way for the creation of each sub-law contained therein.

3. The most applicable law which covers most of the legal parts in it.

The association of human life is governed by various kinds of rules or norms, which in essence aim to produce an orderly and peaceful life together. When undergoing this association of life, humans get empirical facts about how to meet basic needs or primary needs, including among others clothing, food, shelter, safety of life and property, self-esteem, potential for growth and compassion.

Various empirical facts will produce two values at once, positive and negative, so that humans have abstract conceptions of what is good and must be followed, and which are bad and should be avoided. The system of values is very influential on human thought patterns, which is a mental guide for him.

The way or mindset of humans influences their nature, which are tendencies to do or not do something to humans, things or circumstances. Human attitudes then shape the rules, because humans tend to live orderly and properly. An ordered and proper life according to humans is different, therefore standards are needed in the form of rules. Thus it can be said that the rules are the benchmarks or guidelines regarding the expected behavior or behavior. It can also be said that rules are guidelines or benchmarks for how to behave appropriately. In essence a rule is a view of valuing (wardering soordel) on certain behavior from the standpoint of the nature of its nature ${ }^{19}$ called the norm. ${ }^{20}$

In life relationships there are various kinds of rules or norms that become guidelines, namely:

1. The rules or norms that are the rules of life that are accepted as commands, prohibitions and rules that come from God.

2. The rules or norms of decency are the rules of life that come from the hearts of human hearts.

3. Modesty or norms that are rules of life arising from relationships, interactions of human groups in society and regulating human behavior towards other humans.

4. Legal norms or rules, namely regulations made by the authorities whose contents are binding on everyone and their implementation can be maintained with all coercion by the instruments of the state. ${ }^{21}$

Religious norms are based on belief in God Almighty. Religious norms are considered as a provision from God. So the norm of religion or belief is the original social norm from God which contains prohibitions, commands and teachings.

Religious norms are the provisions of human life in a good and right direction. $\mathrm{He}$ regulates human obligations to God and to humans themselves. Violation means defying God's command. As a result or sanctions come from God in the hereafter.

Examples of religious or belief norms are:

1. Don't kill fellow humans.

2. Honor your father's mother

3. Don't act obscene

4. Don't steal. ${ }^{22}$

\footnotetext{
${ }^{19}$ Soerjono Soekanto, Memperkenalkan Sosiologi, Raja Grafindo Persada, Jakarta, 1992, P. 32.

${ }^{20}$ Norma ini berwujud peraturan-peraturan yang menjadi pedoman bagi tingkah laku manusia dalam pergaulan ini, sehingga kepentingan masing-masing dapat terpelihara dan terjamin. Oleh karena itu manusia harus mengetahui hak dan kewajibannya dalam hukum. Lihat OK. Chairuddin, op.cit., P. 92.

${ }^{21}$ Soedjono Dirdjosisworo, op.cit., hlm. 38-40. Lihat juga OK Chairuddin, op.cit., P. 92.
} 
Religion in human life both as individuals and society is a belief system that is part of the value systems that exist in the culture of the community concerned, and becomes a driving force or controller and controller for the actions of the members of that community to keep going in accordance with cultural values and teachings.

Because religion as a source of value for human behavior or actions both individuals and society, while society is dynamic, can change according to conditions, then religion will also change. But what changes in religion are religious traditions or systems of religious belief, while the sacred text or religious doctrine itself, as stated in the scriptures, does not change. ${ }^{23}$ This change is a result of the diversity of interpretations and religious beliefs at the individual and social and group levels and even at the community level. ${ }^{24}$

The rules or norms of decency are the oldest and the most original, also found within the human's own heart because human beings are moral, regardless of nationality or society: "Not heeding moral norms means a moral."25

Ethical norms can be said to be the rules of life that originate from human conscience. He determines what is good and what is bad based on the whisper of his conscience. It is the norm of wisdom that pushes people for the good of their personal morals to perfect themselves.

The moral rules forbid people to commit obscenity, steal and others, because it is felt contrary to the rules of decency that exist in the conscience of every normal human being. Violation of moral norms is a violation of his own feelings. The result or legal sanction is regret. $^{26}$

The norm of decency is the provisions of life that arise from the association of the community. The basic norms of politeness are propriety, habits, propriety that apply in society. Therefore politeness is called norms of courtesy, manners or customs. ${ }^{27}$

So the norms of decency arise and are held by the community itself to regulate relationships so that each member of the community respects mutual respect.

The norms of politeness or the norms of courtesy are aimed at outward attitudes or human behavior for the sake of public order in association in order to achieve an atmosphere of intimacy in association, so that humans as social beings can live together and coexist in the midst of society.

Violations of the norms of decency cause reproach from others. This reproach can be in the form of words but it will be more felt if the reproach is in the form of an attitude of hatred, low view from the people around him, until the culprit is shunned in the association even more intense by boycotting in social life.

Such attitudes cause shame, humiliation, loss of something, exclusion so that they feel inner pain which can be said to be a sanction of punishment.

Next is that the feeling of politeness can be transformed into a feeling of habit. Customs can be transformed into a norm of decency that must be heeded because violations are considered unusual and are considered wrong by the community. Such habits are known as custom. ${ }^{28}$

\footnotetext{
${ }^{22}$ R. Soeroso, Pengantar Ilmu Hukum, Sinar Grafika, Jakarta, 2001, P. 218.

${ }^{23}$ Parsudi Suparlan, dalam kata pengantar Sociology of Religion, Edisi Indonesia Agama Dalam Analisa dan Interpretasi Sosiologi, Raja Grafindo Persada, Jakarta, 1995, P. Xii.

${ }^{24}$ Ibid., hlm. xiii-xiv.

${ }^{25}$ R. Soeroso, op.cit., P. 216.

${ }^{26} \mathrm{Ibid}$.

${ }^{27}$ Ibid., P. 217.

${ }^{28} \mathrm{Ibid}$.
} 
Three norms or norms namely religious, decency and politeness are not enough to guarantee the maintenance of individual interests in association. This is because the three rules do not have strict sanctions, are coercive in life, namely the legal rules which contain: errands (gebol), prohibitions (verbod) and permissibility (mogen). The characteristics that appear in legal norms are:

a. There is coercion from outside (sanctions) from the authorities in charge of maintaining, and fostering public order by means of its instruments.

b. The nature of the law that applies to anyone. ${ }^{29}$

Rule of law that contains orders and prohibitions are inferative means the rules must be obediently a priori obeyed. While the rule of law that contains permissibility is facultative meaning that the principle is a priori not too binding. ${ }^{30}$ The rule of law is aimed at achieving peace in a life together, where peace means a harmony between order and peace or harmony between attachment and freedom. ${ }^{31}$

Legal norms are aimed at human birth attitudes. He does not question whether one's inner attitude is good or bad. What is concerned is how the outward act. Legal norms do not impose sanctions on someone who has a bad mental attitude, but what is sanctioned is the manifestation of a bad mental attitude or making concrete or concrete actions.

Because it is different from the first three norms, violations of legal norms are given a corporal punishment which can be forced by the authorities.

Legal duty is nothing but achieving harmony between legal certainty (zakerheidrecht) and legal comparability (billikheidrecht) simultaneously. If the norms or norms have been understood and obeyed by the community, it can be said that the rules have been institutionalized. The set of rules that are considered by the community to regulate basic needs are commonly referred to as social institutions or social institutions. ${ }^{32}$

Sociologically it is a natural phenomenon that there will be differences between the rules of law on the one hand, and real behavior. This is mainly due to the rule of law as benchmarks about expected behavior in certain things which are abstractions of behavior patterns.

Every society needs a social control mechanism so that everything runs in an orderly manner. What is meant by social control mechanism is everything that is done to carry out the planned and unplanned processes to educate, invite or even force the community members to conform to the rules and values of the community concerned.

Max Weber as quoted by Soerjono Soekanto emphasized the implementation of a centralized power. Weber also said that a sociologist's job is not to judge a legal system, but only to understand it. ${ }^{33}$

\subsection{Law as Social Technology}

Cicero said "yam societas ibi ius", where there are people there is a law. This statement describes that in every society there must be a law, even in the midst of a primitive society. The development of a community will affect the growth of law in that society. One of the

\footnotetext{
${ }^{29}$ Ibid., P. 218.

${ }^{30}$ Purnadi Purbacaraka, Disiplin Hukum adalah Disiplin Sosial, dalam editor Hukum dan Disiplin Sosial, Raja Grafindo Persada, Jakarta, 1988, P. 10.

${ }^{31}$ Soerjono Soekanto, Faktor-faktor yang Mempengaruhi Penegak Hukum, Raja Grafindo Persada, Jakarta, 1983, P. 2.

${ }^{32}$ Soerjono Soekanto, Memperkenalkan...., op.cit., P. 33.

${ }^{33}$ Ibid.
} 
factors that influence the development and change of law in people's lives is the development of science and technology.

Law as a social technology in the sense of law as a tool to change society that might be used as an agent of change. The agent of change is a person or group of people who get the trust of the community as leaders of one or more community institutions. The pioneer of change leads the society in changing the social system and in implementing it is directly linked to pressures to make changes and may even cause changes in other social institutions. A social change that is desired and planned, always under the control and supervision of the pioneers of the change. Ways to influence the community with an organized and pre-planned system, called social engineering or social planning.

As with other areas of life, technology is used to make changes, so also with the legal system as technology in making changes.

The dynamics of society are so high plus the ability of humans to find new variants as a means to facilitate life, making people tend to worry because of the ability of the human mind that is increasingly genius. Of course this is very human, because humans tend to change in a positive direction. Society will automatically switch from traditional life style to modern lifestyle. These changes will take place more quickly, if the community has come into contact with technology.

The undeniable fact that technology has made it easy to meet the needs of his life that continues to grow as if towards no end. Abdul Manan considers that humans do not just defend their lives (survive), but also to develop culture, give meaning to life and humanize humans, encourage people to continue researching, deepening their knowledge. ${ }^{34}$

The development of technology has changed the outlook and lifestyle, including in terms of legal life. For example, technological inventions from the medical side, such as transplantation of human organs.

Transplant or transplant is the removal of organs that still have the life force to replace organs that are not healthy or no longer function. The technology of human organ transplantation in the medical world today still leaves a big question mark, not only on the answer to the question whether it is legal or illegal, but furthermore is whether the donated organ is compatible or not with the patient to be donated?

Other technological findings are in the field of trading business. Currently being loved is what is known as E-Commerce or Electronic Commerce, namely the exchange of business information without using paper but through EDE (electronic data exchane), E-mail, EBB (electronic bulletin board), EFT (electronic fund transfer) who use the internet as a network. In short E-Commerce is the exchange or transaction of goods and services via electronics. ${ }^{35}$

E-Commerce makes users run the principle of efficiency, because it saves in terms of time, cost and convenience in transactions. In addition, with E-Commerce, it is expected that business principles can be carried out properly, because one of the advantages of going on line business is the potential to avoid high operational costs.

E-Commerce is indeed beneficial in terms of comfort and efficiency, but there are many gaps that can be exploited by others to gain as much profit as possible from these transactions by deceiving consumers for example. Therefore the law must be able to provide maximum protection for E-Commerce users.

Now there is also a mode of crime that is very rife and spread in recent times is cyber crime, which if translated meaning is cyber crime by utilizing computer and internet services. This crime can be done without accessing or penetrating the system by taking other people's

\footnotetext{
${ }^{34}$ Abdul Manan, op.cit., P. 161.

${ }^{35}$ Ibid., P. 172.
} 
programs for evil purposes. Last year, Indonesia was horrified by the theft of money through ATMs carried out by a network of criminals whose specialty was breaking into ATMs and then taking a number of customers' money.

Cyber crime is also closely related to economic crime, especially matters relating to money laundering crimes that are mostly committed by illegal business actors. Therefore the law here plays an important role in taking preventive actions so that cyber crime can be minimized.

Other types of crimes that use technology as a tool are corporate crimes, namely crimes committed in groups or together against a trade and business activity that uses electronic services, for example falsifying financial statements. Corporate crime is usually driven by a movement known as the mafia.

Other types of crimes related to technology are piracy of films, books and songs. Indonesia is the number 2 largest country in the world in terms of piracy. In fact, book writers, film players, screenwriters, directors and songwriters struggle to produce their creative works.

Therefore, experts are required to provide various answers and solutions by making legal regulations as a result of major changes in society, as a result of technology and the influence of pressure caused by the development of society. The law here is expected to be able to respond to these changes.

\section{Conclusion}

Law is a social phenomenon that originates from society, is attached to society and is used to regulate forms of relations in society. The law contains the rules, commands and prohibitions that guide the community to act called the rules or norms.

Law is known as a social phenomenon and social rules, law is also seen as a social technology in the sense of law as a tool to change society that may be influenced by views as agents of change.

Besides that the law as a rule can function to channel the direction of the activities of citizens towards the goals and objectives to be achieved by the changes.

\section{References}

Abdul Manan, 2006, Aspek-Aspek Pengubah Hukum, Kencana, Jakarta, Cet. Ke-3.

Adam Podgorechi, Christopher J. Whelan, 1987, Pendekatan Sosiologi Terhadap Hukum, Penterjemah Widyaningsih, G. Karta Saputra, Bina Aksara, Jakarta.

Ahmad Kamil, M. Fauzan, 2008, Kaidah-Kaidah Hukum Yurisprudensi, Kencana, Jakarta, Cet. Ke-3.

Ahmad Musthafa al-Maraghi, t.th., Tafsir al-Maraghi, Juz. I, Bab al-Baby al-Halaby, Kairo.

Amal, K. (2018). The Exploring of Marxism Regarding The Poverty Sustainability in Kampung Nelayan Seberang, Belawan, Indonesia. Budapest International Research and Critics Institute (BIRCI-Journal), p. 79-92.

Baharuddin Lopa, 2009, Permasalahan Pembinaan dan Penegakan Hukum di Indonesia, Bulan Bintang, Jakarta.

Nur A. Fadhil Lubis, 1995, Hukum Islam Dalam Kerangka Teori Fikih dan Tata Hukum Indonesia, Widya Sarana, Medan, Cet. Ke-1.

OK. Chairuddin, 1991, Sosiologi Hukum, Sinar Grafika, Jakarta. 
Parsudi Suparlan, 1995, dalam kata pengantar Sociology of Religion, Edisi Indonesia Agama Dalam Analisa dan Interpretasi Sosiologi, Raja Grafindo Persada, Jakarta.

Purnadi Purbacaraka, 1988, Disiplin Hukum adalah Disiplin Sosial, dalam editor Hukum dan Disiplin Sosial, Raja Grafindo Persada, Jakarta, 1988.

R. Soeroso, 2001, Pengantar Ilmu Hukum, Sinar Grafika, Jakarta.

Satjipto Rahardjo, 1998, Hukum dan Masyarakat, Angkasa, Bandung. , 2000, Ilmu Hukum, PT Citra Aditya Bakti, Bandung.

, 2009, Hukum Progresif Sebuah Sintesa Hukum Indonesia, Genta Publishing, Yogyakarta.

Soedjono Dirdjosisworo, 1988, Pengantar Ilmu Hukum, Rajawali Pers, Jakarta, Cet. Ke-2.

Soerjono Soekanto, 2005, Sosiologi Suatu Pengantar, Yayasan Penerbit UI, Jakarta. , 2003, Faktor-faktor yang Mempengaruhi Penegak Hukum, Raja Grafindo Persada, Jakarta.

, 2008, Antropologi Hukum, Materi Pengantar Ilmu Hukum Adat, Raja Grafindo Persada, Jakarta. , 2002, Memperkenalkan Sosiologi, Raja Grafindo Persada, Jakarta.

Suparman Usman, 2010, Hukum Islam Asas-Asas dan Pengantar Studi Hukum Islam dalam Tata Hukum Indonesia, Gaya Media Pratama, Jakarta.

W. Friedman, 1960, Legal Theory, Stevens \& Sons Limited, London, Edisi ke-4. 